\title{
Herramientas para la transferencia del conocimiento geo-edáfico: aplicación a los viñedos de Secastilla (DO Somontano, NE España)
}

\author{
D. Badía ${ }^{1}$, J.A. Cuchí ${ }^{1}$, J. Casanova ${ }^{1}$, C. Martí ${ }^{1}$, J.M. Rodríguez ${ }^{1}$, J.M. Ayuso ${ }^{2}$, J. Albar ${ }^{2}$ \\ ${ }^{1}$ Escuela Politécnica Superior de Huesca. Universidad de Zaragoza; correo: jcasan@unizar.es \\ ${ }^{2}$ Viñas del Vero S.A. \\ Introducción
}

El suelo, dentro del contexto vitícola, puede considerarse como el nexo de unión entre las viñas y el material parental. El suelo, junto al clima, el relieve y el viñedo, permiten diferenciar un determinado "terroir", un espacio geográfico singular debido a las interacciones entre el medio físico y biológico y las prácticas vitivinícolas que en él se aplican (Morlat, 2010). En este trabajo se proponen diversas acciones para divulgar el conocimiento de los suelos de viñedos en el valle de Secastilla (D.O. Somontano), una zona de interés geomorfológico, geológico, edafológico y también histórico.

En este trabajo se muestran diversas herramientas con las que dar a conocer los suelos y su formación en el valle de Secastilla (D.O. Somontano).

\section{Material y métodos}

Seleccionados los perfiles de suelos más representativos, se describen macromorfológicamente (FAO, 2009) y micromorfológicamente (Benyarku \& Stoops, 2005), y se muestrean para su análisis. De la fracción de tierra fina, se analizan sus principales propiedades físicas y químicas $(\mathrm{pH}$, carbonatos, materia orgánica, CEe, iones en solución, porosidad, estabilidad estructural, CRAD, granulometría, CIC), se clasifican (IUSS, 2007) y se evalúa el potencial de vigor y de precocidad del terreno para la viña (Morlat, 2010). Además, se toman varios kilos de cada horizonte edáfico para disponerlos en cajas de metacrilato y elaborar los monolitos de perfiles. Se identifican los cantos y gravas presentes en los suelos, organizándose en cajas de madera, con una leyenda que indica su naturaleza, edad, origen y localización en la zona de estudio.

\section{Resultados}

La evolución geológica en el valle de Secastilla se sintetiza mediante bloques diagrama con el fin de explicar la presencia y distribución de los materiales parentales de los suelos de la zona. Por otro lado, la diversidad de litologías en el valle de Secastilla, y especialmente la alteración de los conglomerados que aportan multitud de cantos rodados, ha permitido elaborar cajas de rocas.

La posición topográfica, el sustrato geológico conjuntamente con la acción del clima y la vegetación a lo largo del tiempo dan origen a las diferentes clases de suelos. Por otro lado, las imágenes obtenidas con polarizadores paralelos permitieron observar los procesos de calcificación, humificación y gipsificación, Con la información generada se publicaron diferentes paneles y estructuras informativas (figuras 1, 2, 3) 


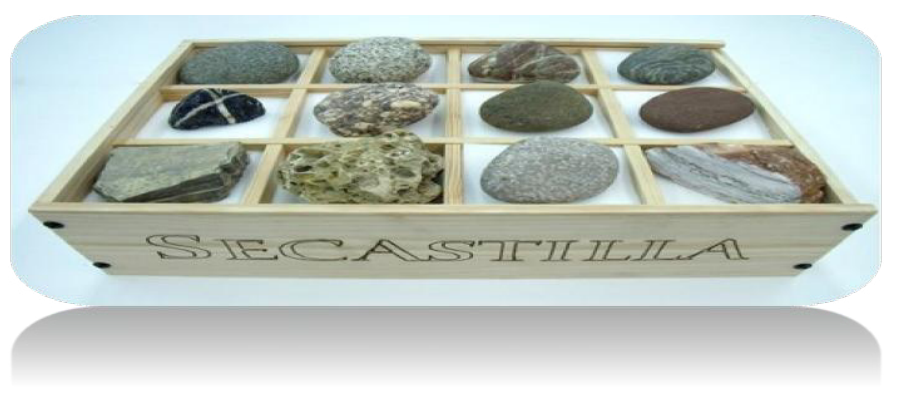

Figura 1: Caja de rocas representando los diferentes orígenes geológicos de los suelos de Secastilla

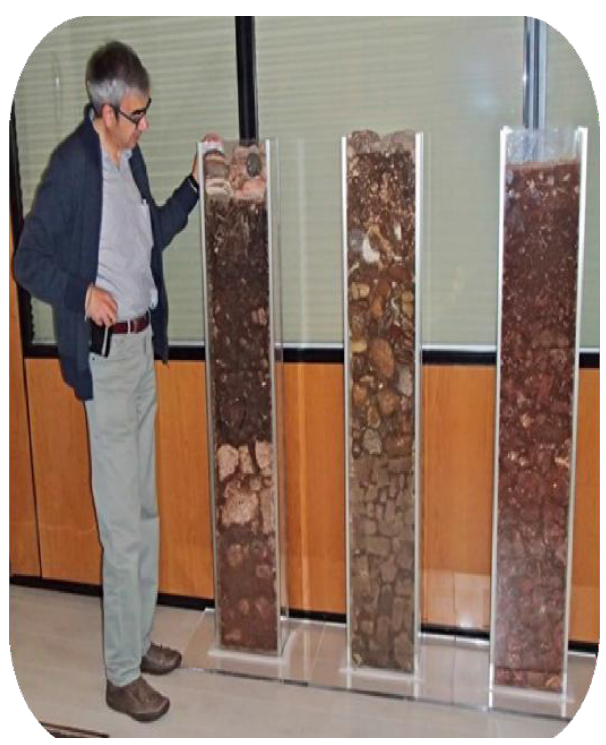

Figura 2: Monolitos de suelos mostrando los diferentes horizontes en cajas de metacrilato
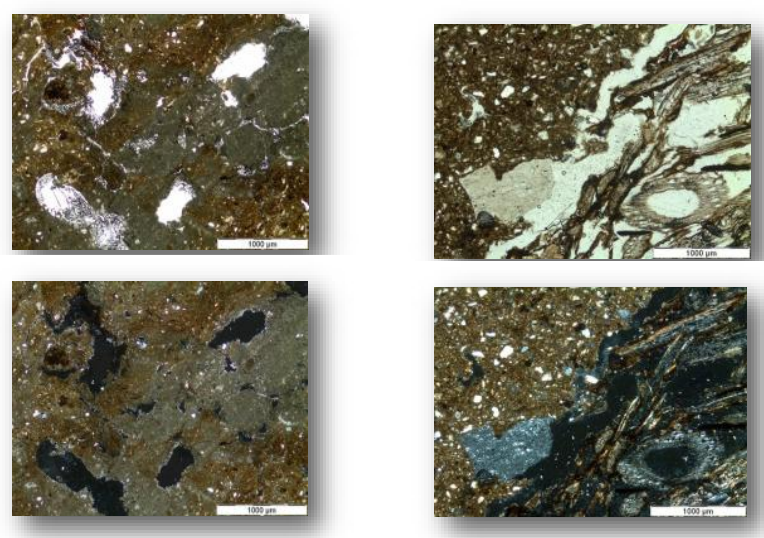

Figura 3: Paneles de microfotografías de los materiales edáficos en la actualidad. Calcificación (Izquierda) y Humificación (Derecha) 


\section{Conclusiones}

A la tradicional caracterización de las propiedades de suelos y su distribución, le acompaña la elaboración de cajas de piedras, monolitos de perfiles de suelos (para su observación en sala y en campo) y paneles que muestran desde la evolución geológica hasta el potencial de vigor del terreno. Suelos y geología se incorporan, así como elementos con los que potenciar el turismo cultural y el eno-turismo en el mundo rural.

\section{Bibliografía}

Benyarku, C. A., \& Stoops, G. (2005). Guidelines for preparation of rock and soil thin sections and polished sections. Departament de Medi Ambient i Ciències del Sòl, Universitat de Lleida.

FAO (2009) Guía para la descripción de suelos. FAO, Roma

IUSS Grupo de Trabajo WRB. (2007). Base Referencial Mundial del Recurso Suelo. Primera actualización 2007. Informes sobre Recursos Mundiales de Suelos No. 103. FAO, Roma.

Morlat, R. (2010). Traité de viticulture de terroir. Editions Tec\&Doc 